\title{
OESTROGENS IN BOVINE FETAL AND MATERNAL PLASMA NEAR TERM
}

\author{
A. J. PETERson, J. T. HUNTER, R. A. S. WELGH AND \\ R. J. FAIRGLOUGH \\ Ministry of Agriculture and Fisheries, Research Division, \\ Ruakura Agricultural Research Centre, Hamilton, New Zealand
}

(Received 8th October 1974)

Administration of exogeneous oestrogens, especially when given early in gestation, will terminate pregnancy in the cow (Hill \& Pierson, 1958). Normal calving is preceded by a rise of oestrogen levels in the maternal peripheral plasma (Smith, Edgerton, Hafs \& Convey, 1973; Robertson, 1974). Although these data suggest that oestrogens may be important in the initiation of parturition, little is known of the source of this oestrogen rise in the cow. It seemed pertinent, therefore, to determine the levels of oestrogens in fetal and maternal plasma over the last 3 weeks of gestation. In the present paper, the levels of free oestrone and oestradiol- $17 \beta$ in the maternal jugular and utero-ovarian vein plasma and in fetal vena cava plasma in relation to the initiation of parturition in the cow were determined by radioimmunoassay.

Catheters were implanted surgically into the maternal utero-ovarian and jugular veins and into the fetal posterior vena cava through the fetal saphenous vein in three cows during the last third of gestation. Fetal and maternal blood samples were taken twice daily until parturition; when calving was imminent, maternal utero-ovarian samples were taken more frequently. Blood was collected into ice-cold, heparinized syringes, centrifuged immediately and the plasma was stored at $-15^{\circ} \mathrm{C}$ until analysis. The plasma was extracted with 10 vols redistilled diethyl ether and chromatographed on micro-columns of Sephadex LH-20 (Wu \& Lundy, 1971). The oestrone and oestradiol fractions thus separated were subjected to radioimmunoassay by the method of Peterson $\&$ Common (1972), using antisera against oestradiol-17 $\beta$-17-BSA and oestradiol$17 \beta-6-\mathrm{BSA}$, respectively. Oestrone cross-reacted $56 \%$ with the oestradiol-17 $\beta$ $17-\mathrm{BSA}$ antiserum and oestradiol- $17 \alpha$ cross-reacted $1.9 \%$ with the antiserum against oestradiol-17 $\beta-6-\mathrm{BSA}$. Over the range of 0.01 to $1.0 \mathrm{ng}$, recoveries of oestrone and oestradiol- $17 \beta$ were of the order of 70 to $80 \%$ and the within-assay coefficient of variation was 10 to $12 \%$. The between-assay coefficient of variation, calculated from control samples run in duplicate with each assay was $15 \%$. The sensitivity of the method, determined from the variability of the reagent blanks, was $5 \mathrm{pg} / \mathrm{ml}$ for oestrone and $4 \mathrm{pg} / \mathrm{ml}$ for oestradiol- $17 \beta$. The results in this paper have been corrected for procedural losses.

The mean values for three cows are presented in Text-fig. 1. The pattern of the free oestrogen levels in jugular plasma was very similar to that reported by 
Smith et al. (1973) and Robertson (1974). The corresponding levels in the uteroovarian vein showed a parallel pattern but with a two- to five-fold higher concentration of both oestrogens. By contrast, the fetal levels of oestrone and oestradiol- $17 \beta$ showed little change towards term.

The difference in oestrogen concentration between utero-ovarian and jugular plasma indicates that the increase in peripheral oestrogen before parturition in the cow is primarily of feto-placental origin. The levels of both free and sulphated (Hunter, Welch, Fairclough, Barr \& Seamark, 1974) oestrogens in fetal plasma

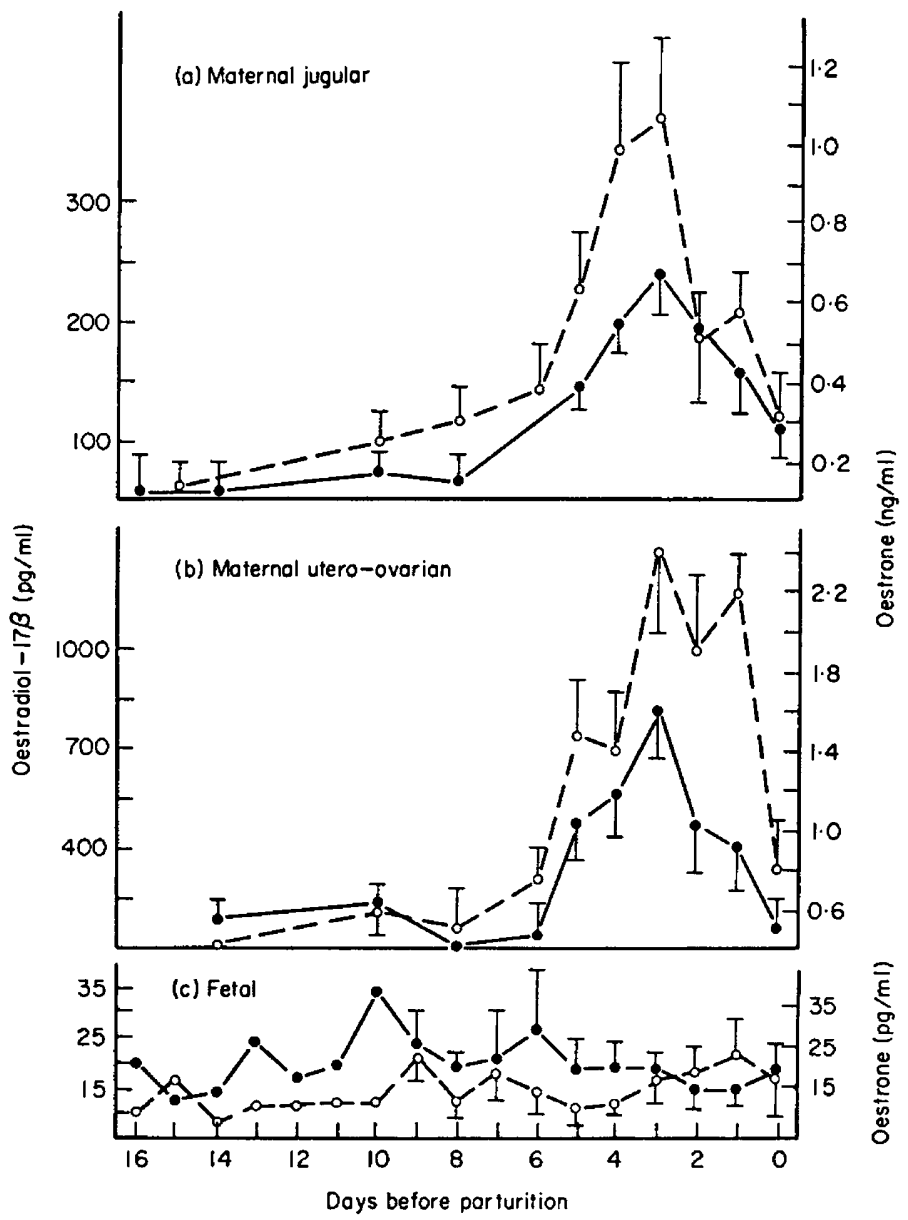

Text-Fic. 1. Concentrations of oestradiol-17 $\beta(\bullet)$ and oestrone $(0)$ in the maternal $(a, b)$ and fetal (c) plasma of three cows and their fetuses near term. Vertical bars represent the S.E.M.

showed little consistent change before calving, however, which is in contrast to the changes that occur before parturition in the fetal lamb and kid (Currie, Wong, Cox \& Thorburn, 1973). The levels of oestrogen sulphates in fetal calf plasma are a 1000-fold higher than the free levels (Hunter et al., 1974) and these high concentrations could serve as a source for the rise in maternal plasma oestrogens before calving. Until data on the secretion rates and placental 
permeabilities of both free and conjugated oestrogens become available however, no definite conclusions as to the rôle of fetal oestrogens in bovine parturition can be reached.

The authors acknowledge the assistance of Mr L. T. McGowan in surgery and blood sampling, and the laboratory assistance of Mrs Patricia Woolford. One of us (A.J.P.) is a recipient of a New Zealand National Research Advisory Council Post-Doctoral Fellowship, and J.T.H. is a recipient of a Ciba-Geigy Postgraduate Scholarship at the University of Waikato, Hamilton, New Zealand.

\section{REFERENGES}

Gurrie, W. B., Wong, M. S. F., Gox, R. I. \& Thorburn, G. D. (1973) Spontaneous or dexamethasoneinduced parturition in the sheep and goat: changes in plasma concentrations of maternal prostaglandin F and foetal oestrogen sulphate. Mem. Soc. Endocr. 20, 95-118.

Hill, H. J. \& Pierson, R. E. (1958) Repositol diethylstilbestrol as an abortifacient in feedlot heifers. 7. Am. vet. med. Ass. 132, 507-512.

Hunter, J. T., Welch, R. A. S., Fairclough, R. J., Barr, H. \& Seamark, R. F. (1974) Fetal oestrogens and maternal progestins when the bovine fetus was infused with dexamethasone. $\mathcal{F}$. Reprod. Fert. 36, 469-470.

Peterson, A.J. \& Common, R. H. (1972) Estrone and estradiol concentrations in peripheral plasma of laying hens as determined by radioimmunoassay. Can. F. Zool. 50, 395-404.

Robertson, H. A. (1974) Changes in the concentration of unconjugated oestrone, oestradiol-17 $\alpha$ and oestradiol-17 $\beta$ in the maternal plasma of the pregnant cow in relation to the initiation of parturition and lactation. 7. Reprod. Fert. 36, 1-7.

Smith, V. G., Edgerton, L. A., Hafs, H. D. \& Gonvey, E. M. (1973) Bovine serum estrogens, progestins and glucocorticoids during late pregnancy, parturition and early lactation. $\mathcal{F}$. Anim. Sci. 36, 391-396.

Wu, G. H. \& Lundy, L. E. (1971) Radioimmunoassay of plasma estrogens. Steroids, 18, 91-111. 